\title{
Wet type of tuberculous peritonitis
}

\author{
Ali Kemal Sivrioglu, ${ }^{1}$ Mehmet Incedayi, ${ }^{2}$ Muzaffer Saglam, ${ }^{2}$ Guner Sonmez ${ }^{2}$
}

${ }^{1}$ Department of Radiology, Aksaz Military Hosp, Mugla, Turkey

${ }^{2}$ Department of Radiology, GATA Haydarpasa Teaching Hospital, Istanbul, Turkey

\section{Correspondence to} Dr Ali Kemal Sivrioglu, draksivrioglu@gmail.com
To cite: Sivrioglu AK, Incedayi M, Saglam $\mathrm{M}$, et al. BMJ Case Rep Published online: [please include Day Month Year] doi:10.1136/ bcr-2013-009259

\section{DESCRIPTION}

A 24-year-old man presented with a 2-month history of mild abdominal pain and persistent fever of $38^{\circ} \mathrm{C}$. The patient had pneumonia 5 years ago. Abdominal ultrasonography showed loculated and free ascites, increase in the mesenteric echogenicity and mesenteric lymphadenopathy. Contrast-enhanced abdominal CT showed large amount of loculated viscous fluid and enhanced diffuse peritoneal thickening. Posteriorly displaced small bowel loops were detected (figure 1A,B). Diagnostic laparoscopy revealed multiple tubercles over the whole peritoneum and the pathology report described granulomatous nodules. Culture of the ascitic fluid revealed Mycobacterium tuberculosis which resulted in a final diagnosis of tuberculous peritonitis (wet type). The patient's fever and abdominal distension gradually decreased after antituberculosis treatment.

Peritoneal tuberculosis (TB) is an uncommon site of extrapulmonary infection caused by $M$ tuberculosis. ${ }^{1}$ It can also occur via haematogenous spread from active pulmonary or miliary TB. Much less frequently, the organisms enter the peritoneal cavity transmurally from the infected small intestine or contiguously from tuberculous salpingitis. ${ }^{2}$

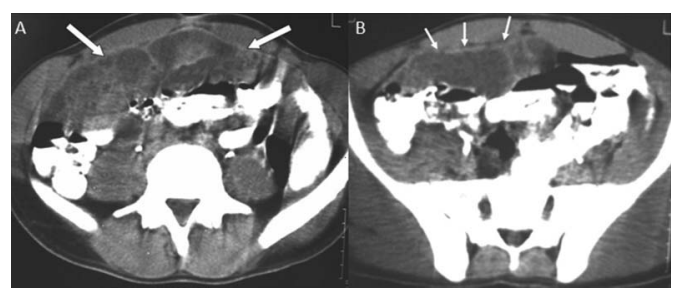

Figure 1 Axial contrast-enhanced CT images showing large amount of loculated viscous fluid (arrows; A) and enhanced diffuse peritoneal thickening (arrows; B). Posteriorly displaced small bowel loops could be seen.
Tuberculous peritonitis is a well-recognised disease which has declined after the introduction of effective antituberculosis drugs. However, the frequency of this disease in developed countries has increased during the last decade and is mainly observed in patients with immunodeficiencies associated with alcoholism, steroid therapy, intravenous drug abuse, chemotherapy and AIDS. Three types of tuberculous peritonitis have been described. ${ }^{3}$ The wet type, which is characterised by a large amount of free or loculated viscous fluid, is seen in most of the patients. The fibrotic-fixed type and the dry or plastic type are less common. A similar peritoneal appearance may occur with carcinomatosis, mesothelioma, or non-tuberculous peritonitis ${ }^{3}$

\section{Learning point}

Three types of tuberculous peritonitis have been described. The wet type, which is characterised by a large amount of free or loculated viscous fluid, is seen in most of the patients. The fibrotic-fixed type and the dry or plastic type are less common.

\section{Competing interests None.}

Patient consent Obtained.

Provenance and peer review Not commissioned; externally peer reviewed.

\section{REFERENCES}

1 Mehta JB, Dutt A, Harvill L, et al. Epidemiology of extrapulmonary tuberculosis. A comparative analysis with pre-AIDS era. Chest 1991;99:1134.

2 Tang LC, Cho HK, Wong Taam VC. Atypical presentation of female genital tract tuberculosis. Eur I Obstet Gynecol Reprod Biol 1984;17:355.

3 Engin $G$, Acunas $B$, Acunas $G$, et al. Imaging of extrapulmonary tuberculosis. RadioGraphics 2000;20:471-88.

Copyright 2013 BMJ Publishing Group. All rights reserved. For permission to reuse any of this content visit http://group.bmi.com/group/rights-licensing/permissions.

BMJ Case Report Fellows may re-use this article for personal use and teaching without any further permission.

Become a Fellow of BMJ Case Reports today and you can:

- Submit as many cases as you like

- Enjoy fast sympathetic peer review and rapid publication of accepted articles

- Access all the published articles

- Re-use any of the published material for personal use and teaching without further permission

For information on Institutional Fellowships contact consortiasales@bmjgroup.com

Visit casereports.bmj.com for more articles like this and to become a Fellow 